\title{
Incorrect Regulation Limiting Space of Movement, Communication Policy Regulation Dilemma Against the Application of Over-the- Top in Indonesia
}

\author{
Zahrina Arum Nabilah \\ Media and Communication Department \\ Universitas Airlangga \\ Surabaya, Indonesia \\ zahrina.arum.nabilah-2019@fisip.unair.ac.id
}

\begin{abstract}
The Ministry of Communication and Informatics is very vulnerable against the odds of incorrect regulations and limiting the movement space of Over-the-top application services. The Tumbrl case in 2018 had also became a clear elaboration regarding regulations resulted from Ministry of Communication and Informatics as still being inadequate, since the utilization of Legislation Law no. 192016 on Information and Electronic Transaction (ITE) and as well Legislation Law no. 442008 on Pornography being on the discourse of content layer imposing against the OTT service provider (Tumbrl). Likewise, a market full of contents, both of good and bad, Ministry of Communication and Informatics tends to utilize tools to burn down the market and close it temporarily, hence limiting space, silencing ideas, and the regulation hasn't come to place yet. Up until its replacement of its minister in 2019, OTT regulation still hasn't been passed. This research give an idea of great opportunity for Ministry of Communication and Informatics to better understand the internet architecture for creating appropriate OTT regulations.
\end{abstract}

Keywords-over-the-top, Communication Policy, Internet Architecture

\section{INTRODUCTION}

The development of Over-the-top (OTT) is then followed by the increase in internet user penetration in Indonesia, being realized by The Ministry of Communication and Informatics as an urgent to set a layout and handle it. According to Rudiantara[1], costumer services, costumer protection, and taxation law became the 3 most urgent aspects regarding OTT in Indonesia. Especially in regards to the foreign ones which are obliged to own an official enterprise body in Indonesia. In the agenda, OTT would be administered within the rules set by Ministry of Communication and Informatics.

Before being passed, various cases relating to OTT service companies came about. The government then had to step up and conduct its function as a system regulator. In some cases, application users having posted contents inappropriate had been prosecuted trough the existing regulations. On 6th March 2018, the Ministry of Communication and Informatics had blocked Tumbrl due to the sheer amount of complaints being made in regards of its improper contents. The Directorate General of Informatics Application, Samuel Abrijani Pangarepan along with his team had yielded a finding of 360 accounts in Tumbrl containing those [2]. Furthermore, Pangerapan issued a reason behind Kemenkofinmo's action is according to the violation of Legislation Law no. 192016 on Information and Electronic Transaction (ITE) and Legislation Law no. 44 2008 on Pornography. The troublesome accounts had caused Tumbrl to be inaccessible and the ITE Law mostly dictates on how one's action in the realm of electronic transaction. Thus focusing more on the apprehending the individual instead of the OTT companies themselves. In this regard it is a dilemmatic one, since the advancement of technology became more rapid but not balanced by its regulations. In addition, OTT had been perceived as contributing and adhering to the pornography, LGBT and terrorism contents.

Apart from the cases of Tumbrl and its counterparts such as Bigo and Tik-tok, Setiawan [3] recorded other problems arising from OTT services. OTT service providers provide economical upgrade by issuing new jobs, such as Go-Jek and Grab, however consumer protection became an issue due to the delay of its regulations.

Other problem lays in the OTT service provider themselves and its internet operator counter parts. Obviously, its existence is a threat towards the internet providers, OTT companies hitch hike on the telecommunication and infrastructure web provided by the likes of Telkomsel and Indosat. However, OTT had absolutely no direct link towards those companies, or their income other than the monthly internet data package bought by the costumer to access them. Not to mention the drop-in call and SMS services between the providers due to the increase of internet connection towards Whatsapp and Facebook Messenger by OTT users. Furthermore, operators felt as being at lose. Noted from the Ministry of Communication and Informatics [4], Indonesia's Telecommunication Association (ATSI) released a data, stating that telecommunication growth in the country had shrunk by $6,4 \%$ in 2018 .

The contraction was caused by several important factors, including the decrease of voice/SMS service which had been replaced by Over-the-top (OTT) provider, tariff war among operators at data service, and as well as SIM Card registration regulation [4].

This paper focuses on the incorrect decision on law usage which closed movement space for OTT. This is because there still hasn't been a regulation in place, by taking account the 
Tumbrl blockade case by Ministry of Communication and Informatics. Rudiantara, had actually stated a regulation implementation on OTT since 2016 after the commitment made by Google Asia Pacific Ltd began to pay off its debt in Indonesia [5]. Earlier, Rudiantara had also published an Issued Statement (SE) No. 32016 on Application Service Providence and/or Content through Internet (Over-the top), however up until now it hasn't been realized.

On the other hand, the government took into account other rule, which in this case is The Legislation Law no. 192016 on Information and Electronic Transaction (ITE) and Legislation Law no. 442008 on Pornography, in order to block OTT companies and further push it away from the market place of ideas principle as had been stated by Napoli[6].In the analysis part, the writer proposes internet architecture theory approach from Solum and Chung [7] as a suggestion for the government upon forming regulations. The writer will also provide other perspectives from regulation in other countries in further discussion.

\section{RESEARCH METHOD}

This research utilized qualitative method with descriptive approach analysis. The primary and secondary data was collected through literature study and official government documents that are publicly accessed from The Ministry of Communications and Informatics website. The use of Legislation Law was also analyzed more seriously by involving available information from the mass media.

\section{LITERATURE REVIEW}

\section{A. Over-the-top Regulation in Indonesia}

Over-the-top (OTT) service covers all kinds of social media services, video streaming, music, and internet connection-based picture sending from provider or internet service operator. There are three things interconnecting in the process of OTT, which are OTT World, OTT Service, and Telco World. Telco World is an Internet Service Provider including its operators. In Indonesia, Telco World could be in the forms of Telkom, XL, IM3 Oredoo, and Telkomsel, tasked with all the facilities, including infrastructures, connection and communication line to ensure the OTT functions. OTT World is an environment of OTT itself which are consisted of application and OTT-based services such as Youtube and Facebook. While OTT Services are the junction between the two where all kinds of application and OTT services can operate with the existing internet service providers.

Starting from the year of 2010, when The Ministry of Communication and Informatics Tifatul issued a Ministerial Regulation Draft regarding Multimedia which was then declined and halted since it was perceived as abolishing the press and people freedom in using the internet. Ministry of Communication and Informatics then planned for the regulation of OTT by issuing a Minister's Bill on Internetbased Application or Content Service Provider (OTT) under the administration of Rudiantara. Not having materialized yet, but this enabled the explanation for the majority of population and OTT Service Providers in which every stakeholder was asked to implement the OTT regulation and provide adequate time for everyone involved.
On the issued bill, application service through the internet concludes all activities such as message sending including video, purchasing transactions, games, and social web. While internet-based content service covers all forms of music, video, film, audio, picture, including downloaded or uploaded animation. Both, internet and content service-based application benefitting from the telecommunication service through internet protocol-based telecommunication web. These internet-based application or content service providers are known as Over-the-top service.

Though still not materialized into rules, the OTT bill possess a source of law and policy, such as The Legislation Law no. 361999 regarding Telecommunication and The Legislation Law no. 112008 on Electronic Information and Transactions. Within it, encompassing the Over-the-top Service Provider's Obligation and prohibited service points.

"Provision of Excessive Services provides services that have the following content:

5.6.1 Contrary to Pancasila and the 1945 Constitution of the Republic of Indonesia, challenging the integrity of The Republic of Indonesia;

5.6.2 Causing contention or conflict between groups, ethnic groups, religions, races, and other groups (SARA), defaming, harassing, and / or tarnishing religious values;

5.6.3 Encourage the general public to take actions against the law, violence, narcotics, psychotropic and other addictive substances abuse, degrading human dignity, morality and pornography, gambling, humiliation, blackmailing or checking, defamation, hate speech, violation towards intellectual property rights; and / or

5.6.4 Contrary to statutory provisions" [8]

After being issued, the public specifically the OTT service industry involved waited for the official regulation to take form. As cited by kumparan.com [9], Minister Rudiantara had stated that the OTT Law would soon materialize by the end of 2017. This was declared after Google paid-off its tax. Further explained by Ardhian [10], through the media coverage on the ministry's official website, it admitted that the Google issue of not having paid its tax was the main thing standing from The Minister's Bill legalization

"First, in the regulation itself the government still has not completed the detailed rules related to the existence of national OTT, so that it has the same playing field level as the foreign ones. However, this can be resolved immediately. Second, the most influencing matter is in regards to the tax rules of the national and foreign OTT. Rudiantara acknowledged, Google's tax problem that has not been resolved causes this OTT Regulation to be absent [10]"

Beside Indonesia, other countries such as Australia and Spain have had their share of pursuing Google in the sense of its disobedience on tax. In 2017, it was asked to pay its unregistered tax in the sum of Rp 2,75 trillion. This payment was based on the Legislation Law no. 172000 regarding PPh, on article 26 in which since 15th September 2011 Google had been registered as foreign venture assessable, Google Singapore Ptw Ltd. In regards of this tax, The Ministry of Finance supported by Ministry of Communication and Informatics aided each other in resolving the issue. Regarding the OTT Law, it was clear on Ministry of Communication and Informatics's turf, however regarding billing and 
enforcement, The Ministry of Finance through The Tax General Directorate has the upper hand.

Republic of Indonesia's First Commission Parliament Member PKS Fraction Sukamta stated that Ministry of Communication and Informatics should not only be in position of material allocation (tax and royalty) but also immaterial limitation which is in the realm of OTT service field theme in the hopes of digital sovereignty establishment. The delayed in Ministry of Communication and Informatics's Minister Bill approval on OTT, The General Directorate of Informatics Application on behalf of the ministry had seized on the arrangement of the regulation [11].

Up until 2020, Ministry of Communication and Informatics still had not issued Ministerial Regulation on OTT. Even though that, foreign OTT companies that own physical offices in Indonesia such as Google and Facebook, had now been tied under the Finance Ministerial Regulation No. 35/PMK.03/2019 regarding Permanent Business Unit (PBU)

"Article 5 (1) The PMK states that one of the PBU locations, an activity in the form of a computer, electronic agent or automatic equipment that is owned, leased or used by a foreign private person or foreign entity to run a business through the internet." [12]

The issue of regulation on OTT companies with physical presence in Indonesia could be regulated by the Ministry of Finance.

Like written on the bill issued by The Minister of Communication and Informatics on Internet-based Application or Content Service Provider (OTT), within the Minister's Regulation draft [8], divides it into two, internetbased Application Service and internet-based Content Service. This regulatory draft also dictates on the OTT service provider criteria which states that a foreign OTT company is mandated to have Permanent Business Unit (PBU) and specific tax terms set. Obligations of OTT Service Providers, its Cooperation with a telecommunications provider, information Contact Centers requires OTT service Providers to provide an information contact center for user complaints, data storage, and loss mitigation. Oversight and control over the implementation of Ministerial Regulations implemented by BRTI, Regulations on Sanctions, Forum on OTT services provided by the government, and regulations in the Ministerial Regulation draft regarding Transitional Provisions for OTT service providers that had been in operation before the Ministerial Regulation was passed.

\section{B. Market Places of Ideas in the Basic Regulatory Communications Principle}

The implementation of Market Places of Ideas according to Napoli [6] could merely be comprehended in the context of basic communication regulation. It may be known that the origin of Market Places of Ideas concept for basic communication regulation sparked from a research conducted by Sweeney and Hopkins, in a metaphor used at a high court conclusion. The research resulted in an insight on how Market Places of Ideas became a factor in decisionmaking process at the high court.

Schauer in Maggiore [13] stated that the Market Places of Ideas theory focuses on the truth to exist when all suggestions could freely be expressed in a free market and without a rule on traded ideas. Furthermore, Schauer [13] stated that the second basic assumption from Market Place of ideas carries all ideas and opinions that might not be correct into the free market for knowledge to compete. This led to a field of knowledge to thrive perpendicularly with all the desired answers. John Stuart Mill emphasized that if we were to listen to everyone's perspective, we would know the best.

\section{Over-the-top regulation in another country}

OTT can become an interesting topic to talk about with different perspectives from around the world. Ganuza and Viecens [14] records that 3 different countries with almost the same problem faced in Indonesia. Like in Korea, telephone operators face problem due to the decrease of voice calls caused by internet and its applications. In Europe, the telephone operator revenues had plummeted as a result of OTT such as Whatsapp and other social web; Facebook and Twitter usage. In Latin America, the surfacing impact of OTT content on online video replaces the role of traditional Television. Additionally, this article provides a new look on OTT regulations in other countries. With almost 450 millions of active monthly user, India is now the 2nd biggest internet user in the world just behind China [15]. The statistics data also shows that India's internet user would grow about $59 \%$ in 2021 from just $28 \%$ in 2016 [16].

In India, there is The Telcom Regulatory Authority of India (TRAI) as a body to regulate telecommunication service and provide fair policy in a competitive environment among providers. TRAI was established on 20th February 1997 by The Parliamentary Regulation. In India, operator as mentioned in Consultation Paper on Regulatory Framework for Over-the-top (OTT) services as Telco Service Provider (TSP). In the context of India, TSP had been regulated in India's Telegraph Law of 1885 (Telegraph Act), TRAI Act, and other various licensing agreements created between TSP and The Indian Government.

India is undergoing an effort in regulating OTTs by forming Consultation Paper on Regulatory Framework for Over-the-top (OTT) services which was introduced on 27th March 2015 and disclosed on 8th May 2015[17]. It invited the stakeholders and officials to contribute suggestions and opinions regarding OTT-related regulations. TRAI then showed its result of suggestion or comments on OTT into three categories, from Service Providers, Service Providers Association and other stakeholders such as organizations, legal bodies, etc. However, TRAI conducted the extension of Consultation Paper on Regulatory Framework for Over-thetop (OTT) services on November 12th 2018 and closed its consultation session regarding OTT on January 7th 2019[18]. Currently, from the research result TRAI had not issued its official regulation on OTT yet.

\section{RESULT AND DISCUSSION}

The incorrect decision on law usage causes a closed movement space for OTT, according to Solum and Chung [7] the communication regulation policy on the internet is categorized as bad if it attacks the content layer by implementing regulation at the physical layer, vis-versa. In this case, it can be seen that The Legislation Law no. 192016 on Information and Electronic Transaction (ITE) and Legislation Law no. 442008 on Pornography lays at the 
content targeting the physical layer of OTT service provider (Tumbrl). In their journal, The Layer Principle: Internet Architecture and Law, Solum dan Chung [16], answered on how the internet architecture comprising of six layers had impacted the form and content of global internet network regulation and law.

Like what Solum and Chung [7] had stated, the role of internet in enabling innovation is not a coincidence; but rather a flowed from the Internet architecture. The main feature enabling its innovation is consisted of layer, being narrowly understood as code or broadly as a functional component from the communication system.

"The Content Layer: The symbols and images that are communicated;

The Application Layer: The programs that use the Internet, e.g., the Web;

The Transport Layer: TCP, which breaks the data into packets;

The Internet Protocol Layer: IP, which handles the flow of data over the network;

The Link Layer: The interface between users computers and the physical layer; and

The Physical Layer: The copper wire, optical cable, satellite links, etc. We flesh out this skeletal description in greater detail below." [7]

Besides, the issue with the Minister's Statement on OTT not being passed yet, causing its movement space being limited by the incorrect regulation, this clearly violates the basic communication principle policy as up-held by Napoli [6]. The principle idea from Marketplace of ideas is that of a space to deliver various ideas into the market and to produce a truth. In this case, when the ministry decided to block Tumbrl as an OTT service, it had really killed off the space for ideas to bloom, which are the contents that did not violate any law. This is in line with what had been proposed by Solum and Chung [7]; "the first theme is grounded in a fact that arises from the layered nature of the Internet: regulations that violate layering (or cross layers) inherently interfere with substantial innocent uses of the Internet." It is then illustrated precisely by Ministry of Communication and Informatics, Solum and Chung [7] gave instances on how a nation handles pornography by cutting off the application layer, which enables to upset that kind of content, however the beneficial ones such as live baseball matches, latest scientific journals had also been eliminated in corresponding to global network being abolished.

"Takedown obligations: Section 69A of the IT Act empowers the Central Governmentto issue directions to any intermediary for blocking for public access of any informationin any computer resource. The provision also prescribes a punishment of imprisonmentupto seven years for any intermediary who fails to comply with the direction issuedunder it" [18]

\section{CONCLUSION}

Not having been passed yet, The Ministry of Communication and Informatics is very vulnerable against the odds of incorrect regulations and limiting the movement space of Over-the-top services. The Tumbrl case had also became a clear elaboration regarding regulations resulted from Ministry of Communication and Informatics as still being inadequate, since the utilization of Legislation Law no.
192016 on Information and Electronic Transaction (ITE) and as well Legislation Law no. 442008 on Pornography being on the discourse of content layer imposing against the OTT service provider (Tumbrl). The blockade of Tumbrl as an OTT service then became an issue because it killed the communication regulation principle which is the marketplace of ideas. Likewise, a market full of contents, both of good and bad, Ministry of Communication and Informatics tends to utilize tools to burn down the market and close it temporarily, hence limiting space, silencing ideas, and the regulation hasn't come to place yet. Up until its replacement of its minister in 2019, OTT regulation still hasn't been passed. The OTT regulation law in Indonesia is still on the level of determining it at The Finance Minister's Statement No. 35/PMK.03/2019 regarding Official Enterprise Body (BUT). This came as great opportunity for Ministry of Communication and Informatics to better understand the internet architecture for creating appropriate OTT regulations.

\section{ACKNOWLEDGMENT}

This article submitted in 2nd Jogjakarta Communication Conference. Thanks to Allah and Ibu Titik Puji Rahayu for giving me this task to do in our media and communication class.

\section{REFERENCES}

[1] A. Syafril, "Menkominfo jelaskan alasan penerbitan aturan OTT," Antara News, 2016. https://www.antaranews.com/berita/550057/menkominf ojelaskan-alasan-penerbitan-aturan-ott.

[2] Y. H. Widiartanto, "Tumblr Diblokir di Indonesia, Ini Penjelasan Kominfo," Kompas.com, 2018. https://tekno.kompas.com/read/2018703/07/16433837/tu mblr-diblokir-di-indonesia-ini-penjelasan-kominfo (accessed Dec. 12, 2019).

[3] A. B. Setiawan, "Policy Development Towards Application and Contents Service Providers on Digital Ecosystem Through Over the Top," J. Penelit. Pos dan Inform., vol. 8, no. 2, p. 169, 2018, doi: 10.17933/jppi.2018.080206.

[4] F. Setu, "Siapkan Aturan Konsolidasi untuk Sehatkan Industri Telekomunikasi Indonesia," Kementerian Komunikasi dan informatika, 2019. https://www.kominfo.go.id/content/detail/18446/siaranpers-no96hmkominfo052019-tentang-siapkan-aturankonsolidasi-untuk-sehatkanindustri-telekomunikasiindonesia/0/siaran_pers.

[5] Fadhil, "Pajak Google tuntas, Kominfo Siapkan Permen OTT," Kementerian Komunikasi dan informatika, 2017. https://kominfo.go.id/content/detail/9991/pajak-googletuntas-kominfo-siapkan-permen-ott/0/sorotan media (accessed Nov. 10, 2019).

[6] P. M. Napoli, Foundation of Communications Policy. New Jersey: Hampton Press, Inc., 2003.

[7] L. B. Solum and M. Chung, "The layers principle: Internet architecture and the law," Notre Dame Law Rev., vol. 79, no. 3, pp. 815-948, 2004, doi: 10.2139/ssrn.416263.

[8] Minister of Communication and Informatics, "Rancangan Peraturan Menteri Komunikasi dan Informatika Republik Indonesia Tentang Penyediaan Layanan Aplikasi Dan/Atau Konten Melalui Internet," $2016 . \quad$ [Online]. Available: https://web.kominfo.go.id/sites/default/files/users/4761/ Draft Uji PUblik Rancangan Permen Kominfo tentang Penyediaan Layanan Aplikasi.pdf.

[9] Redaksi Kumparan.com, "Menkominfo: Aturan OTT Terbit 2 Minggu Lagi," Kumparan.com, 2017. https://kumparan.com/kumparantech/menkominfo- 
aturan-ott-terbit-2-minggu-lagi (accessed Nov. 10, 2019).

[10] M. Ardhian, “Aturan Bisnis Perusahaan OTT Terganjal Pajak Google," kominfo.go.id, 2017. https://www.kominfo.go.id/content/detail/8871/aturanbisnis-perusahaan-ott-terganjal-pajakgoogle/0/sorotan_media.

[11] Minister of Communication and Informatics, "Kominfo kembali bahas aturan untuk OTT," 2018. https://kominfo.go.id/content/detail/14180/kominfokembali-bahas-aturan-untuk-ott/0/sorotan_media (accessed Nov. 11, 2019).

[12] H. Friana and H. id/dle. Baca selengkapnya di artikel "Google dkk Kini Sulit Berkelit dari Pajak Usai PMK BUT Diteken," "Diteken, Google dkk Kini Sulit Berkelit dari Pajak Usai PMK BUT," Tirto.id, 2019. https://tirto.id/google-dkk-kini-sulit-berkelit-dari-pajakusai-pmk-but-diteken-dlet (accessed Nov. 13, 2019).

[13] P. Maggiore, "Viewer Discretion Is Advised: Disconnects Between the Marketplace of Ideas and Social Media Used to Communicate Information During Emergencies and Public Health Crises.," Michigan Telecommun. Technol. Law Rev., vol. 18, no. 2, pp. 627-660, 2012, [Online].
http://libproxy.sdsu.edu/login?url=http://search.ebscoho st.com/login.aspx?direct=true $\& d b=a p h \& A N=78311008$ \&site=ehost-live.
[14] J. J. Ganuza and M. F. Viecens, "Over-the-top (ott) content: Implications and best response strategies of traditional telecom operators. Evidence from Latin America," Info, vol. 16, no. 5, pp. 59-69, 2014, doi: 10.1108/info-05-2014-0022.

[15] M. Mandavia, "India has second highest number of Internet users after China: Report," economictimes.indiatimes.com, 2016. https://economictimes.indiatimes.com/tech/internet/indi a-has-second-highest-number-of-internet-users-afterchina-report/articleshow/71311705.cms (accessed Nov. 14, 2019).

[16] Cisco, "India - 2021 Forecast Highlights," USA, 2016. [Online]. https://www.cisco.com/c/dam/m/en_us/solutions/servic e-provider/vni-forecasthighlights/pdf/India_2021_Forecast_Highlights.pdf.

[17] Telecom Regulatory Authority of India, "1st Consultation Paper on Regulatory Framework for Overthe-top (OTT) services," New Delhi, 2015. [Online]. Available: https://main.trai.gov.in/sites/default/files/OTT-CP27032015.pdf

[18] Telecom Regulatory Authority of India, "Consultation PaperonRegulatory Framework for Over-The-Top (OTT) communication Services," New Delhi, 2018. [Online]. Available:
https://main.trai.gov.in/sites/default/files/CPOTT12112 018.pdf\%0D. 